\title{
Rare and new Laboulbeniales from Poland. VIII
}

\author{
TOMASZ MAJEWSKI
}

Institute of Botany, Polish Academy of Sciences, 00-478 Warszawa, al. Ujazdowskic 4. Poland

Majews K i T, Rareand new Laboulbeniales from Poland. VIII. Acta Mycol. 19(2): 183-191. 1983.

Stands were reported for 10 species of Laboulbeniales new for Poland, including those new for science: Euphoriomyces huggertii on Proteinus brachypterus and Acrulia inflata, Hydrophilomyces pusillus on Ochthebius minimus, Rickia georgit on Hypoaspis cuneifer and Rickia proteini on Proteinus spp.

\section{Acompsomyces atomariae Thaxter}

On Atomaria gutta Steph. (Col., Cryptophagidae): Munina near Jarosław (Przemyśl voivodeship), on a field near the San river, on the ground under Avena sheaves, 11.8.1982 (TM. 2618); on Atomaria gravidula Er.: as previously (TM. 2619, 2620).

On elytra and metathorax of three beetle specimens, 13 fungal thalli - in most cases mature ones - were found. Their dimensions were: length 113-164 $\mu \mathrm{m}$, perithecia $66-100 \times 30-48 \mu \mathrm{m}$, free appendage length $35-43 \mu \mathrm{m}$. They are in accord with the description and drawings of $\mathrm{T}$ h a x $\mathrm{t}$ e $\mathrm{r}$ (1908: 299, pl. 42: 6-9). In this description, the length of perithecium is stated mistakenly. This fungus, described from USA, has not so far been reported apart from locus classicus.

\section{Cantharomyces numidicus Maire}

On Trogophloeus arcuatus Steph. (Col., Staphylinidae): Cieszyn (Bielsko-Biała voiv.), Guldowy district, on the bank of the Bobrówka river, 22.5.1979 (TM. 2187-2194); on Trogophloeus anihracinus Muls.: as previously (TM. 2195).

The abundant material from various host body parts comprises 5 mature and more than 80 immature specimens at various developmental stages. Some of them resemble the immature type of this species, described from North Africa by M a i re (1920: 132-135, Fig. 3), and some are identical with those recently found in Italia (R os s i, C es a r i R oss i 1978). The length of the mature specimens from Poland is $180-290 \mu \mathrm{m}$, perithecia $88-113 \times 38-56 \mu \mathrm{m}$. 


\section{Dimorphomyces myrmedoniae Thaxter}

On Ischnopoda (Tachyusa) constricta (Er.) (Col., Staphylinidae): Munina near Jarosław (Przemyśl voiv.), moist sand on the bank of the San river, 10.8.1982 (TM. 2599-2604); Jarosław, Łazy Kostkowskie, bank of the San river, 15.8.1982 (TM. 2654); Stary Sącz (Nowy Sącz voiv.), moist sand on the bank of the Dunajec river, 25.8.1982 (TM. 2704); as previously, bank of the Poprad river, 25.8.1982 (TM. 2724,2725 ); the same stand, 27.8.1982 (TM. 2739-2741). On Gnypeta rubrior Tott.: Stary Sacz, bank of the Dunajec river, 25.8.1982 (TM. 2695-2699, 2703); as previously, bank of the Poprad river, 25.8.1982 (TM. 2719); the same stand, 27.8.1982 (TM. 2736-2738, 2742). On Atheta fungi (Grav.): Stary Sacz, bank of the Dunajec river, 25.8.1982 (TM, 2702).

The abundant material from Poland comprises well developed female specimens agreeing with the description and dravings of Th a x t e r (1908:240, pl. 28: 14-16). They have up to 6 mature perithecia, and up to 14 cells in the axis of the secondary receptacle; the length of perithecium attains $113 \mu \mathrm{m}$, and that of the secondary receptacle $-100 \mu \mathrm{m}$. The length of the male specimens does not exceed $50 \mu \mathrm{m}$. The Polish material is characterized by high individual variation described also by $\mathrm{T}$ h a x t $\mathrm{c}$ r: many specimens are more or less degenerated, and are less well developed. This fungus occured over the whole body of small representatives of subfamily Aleocharinae, living together in muddy sand on river banks in villy regions. It seems that since its finding by $T$ h a x $t$ e $r$ on beetles from Guatemala, it was not found anywhere for a second time.

\section{Dioicomyces anthici Thaxter}

On Anthicus flavipes Panz. (Col., Anthicidae): Pilica near Warka (Radom voiv.).), sandy bank of the Pilica river, 27.6.1980 (TM. 2411, 2412).

Three well-formed female specimens and three male specimens, found on host elytra, can be classed among Dioicomyces anthici, though with some reservations. Their traits are consistent with the description and dravings of $\mathrm{T} h$ a x t e r (1908: 294, pl. 42: 18-25; 1931: 62, pl. 11: 45-48). The length of the male specimens is 48-50 $\mu \mathrm{m}$ and of the female ones 175-190 $\mu \mathrm{m}$. Perithecia (dimensions $110-115$ $\times 63-68 \mu \mathrm{m})$ are markendly bent; in outline, they are more rounded and broader. as compared with $\mathrm{Th}$ axter's drawings, perhaps owing to compression by the microscopic cover slide. Species known from Central and North America and from Africa; from Europe (Hungary) reported by Bán heg y i (1944).

\section{Diplomyces clavifer W. Rossi et Cesari}

On Erichsonius cinarescens (Grav.) (Col., Staphylinidae); Giby (Suwałki voiv.), in Sphagna on the bank of a small lake in reservation Tobolinka, 19.8.1978 (TM. $2750,2751)$. 
The few specimens found ( 5 immature, 2 mature) agree to a great extent with the diagnosis and photographs of the type ( $R$ os s i, C es a r $i$ 1978). The length of the mature specimens is 108 and $115 \mu \mathrm{m}$, perithecia 58-61 $\times 16-20 \mu \mathrm{m}$; one specimen has two well-developed perithecia, and the other-one perithecium. All fungi were found on the upper surface of the host abdomen.

\section{Euphoriomyces huggertii sp. $\mathrm{n}$.}

Thallus flavus. Axis receptaculi e sex bis octo cellulis constat. Cellula quarta maxima, cellula quinta cum cellula pedunculi perithecii vel cum duabus cellulis pedunculorum lateraliter connexa est. Ex cellula sexta receptaculi cellula subconica basalis antheridii primarii oriur. Supra cellulam distalem receptaculi appendices dichotomicae oriuntur, cuius cellulae angustae et elongatae sunt. Perithecia irregulariter elongatae, collum perithecii breve.

Longitudo tota ad apicem perithecii (70-190-190 $\mu \mathrm{m}$, perithecia (37-)55-200 $\mathrm{x}$ 18-30 $\mu \mathrm{m}$, appendices ad $190 \mu \mathrm{m}$.

Yellowish. The axis of the receptacle consisting of seven to eigth superposed cells; the lower ones (except the basal cell) somewhat flattened, the upper cells rather elongated. The fourth cell larger than the other ones, gradually narrowing towards the base and the distal end of the receptacle. The fith cell laterally connected with the stalk cell of the perithecium or with two such cells. On the sixth cell, somewhat laterally, a small conical cell with the primary antheridium (?) being in the very young specimens at the distal end of the receptacle. The distal cell of the receptacle giving rise to the appendage dichotomically ramified above their base and consisting of relatively slender and elongated cells. The perithecia irregularly elongated, with short neck. The fully developed perithecia located only on the external sides of the paired thalli.

Total length to the tip of perithecium (70-)90-190 um, perithecia (37-)55-200x 18-30 $\mu \mathrm{m}$, appendages (from the base of the seventh cell of the receptacle) up to 190 $\mu \mathrm{m}$.

On Proteinus brachypterus F. (Col., Staphylinidae): Bieszczady Mts., Wetlina (Krosno voiv.), under the bark of overthrown trunks of Fagus sylvatica in Fagetum on the eastern mountain-side of Jawornik, about $700 \mathrm{~m}$ above sea level, 29.5.1974 (TM. 1395); as previously, 2.6.1974 (TM. 1418 - holotype, 1419); the same mountain-side, on small agarics in Fagetum, 2.6.1974 (TM. 1423). On Acrulia inflata Gyll. (Staphylinidae): Bieszczady Mts., Bereżki (Krosno voiv.), in bedding in Fagetum on the bank of the Wolosaty stream, 12.9.1972 (TM. 1113-1116); Bialowieza National Park (Bialystok voiv.), section 314, Circaeo-Alnetum on the bank of the Orlowka river, on decaying polypores, 22.5.1973 (TM. 1255, 1256); Stary Sącz (Nowy Sącz voiv.), thicket near the Dunajec river, in decaying wood, 27.8.1982 (TM. 2735). Leg. T. M ajewski. Fig. 1. 
Euphoriomyces huggertii markedly differs from the so far described representatives of genus Euphoriomyces. The relatively simple structure of its receptacle somewhat resembles that found in E. octotemni ( $\mathrm{M} \mathrm{a} \mathrm{j} \mathrm{e} \mathrm{w} \mathrm{s} \mathrm{k} \mathrm{i} \mathrm{1973).} \mathrm{This} \mathrm{species}$ occurs on different parts of host body. It is variable; the different specimens greatly differ in size, degree of appendage branching etc. Fungi from Acrulia inflata are usually smaller than those from Proteinus brachypterus; they have thinner appendages and an only small initial structure of the second perithecium. However, their variation ranges overlap each other, and thus there are no essential defferences justifying the description of these fungi as distinct taxons.

I should like to dedicate this species to the Swedish laboulbeniologist, Dr. Lars $\mathrm{H} \mathrm{u} \mathrm{g} \mathrm{g} \mathrm{e} \mathrm{r} \mathrm{t,} \mathrm{who} \mathrm{started} \mathrm{studies} \mathrm{on} \mathrm{these} \mathrm{fungi} \mathrm{in} \mathrm{his} \mathrm{country.}$

\section{Hydrophilomyces pusillus sp. $\mathrm{n}$.}

Thallus hyalinus, perithecium flavum. Receptaculum crassum, ex sex vel pius quam sex cellulis constat. Cellulae sustinentes tres, acutae, eis paries incrassatus. Cellula pedunculi perthecii parva, lateralis. Perithecium collum breve ac indistinctum, valde recurvatum habet, sub apicem hemiglobosa protuberatio. Cellulae appendicis isodiametricae, in parte superiore appendicis cum unicis parvis cellulis ex quibus ramuli oriuntur.

Longitudo tota 150-180 $\mu \mathrm{m}$, perithecia 90-115 $\times 35-43 \mu \mathrm{m}$, receptaculum 50-65 $\mu \mathrm{m}$, appendices ad $75 \mu \mathrm{m}$.

Hyaline, perithecium yellowish. Stout receptacle consisting of six cells or more, if the two great, irregular isodiammetric upper cells are secondarily divided. The cells of the receptacle above the basal cell are vertically divided and produce three thick-walled, nearly sharp-pointed buffer cells. The stalk cell of the perithecium is relatively small, irregular, laterafly situated; the basal cells are small and flattened. The perithecium with short, slightly differentiated neck which is strongly curved outwards; below the apex, a prominent hemispherical protuberance is present. The external wall-cell flattened, indistinct. Appendage consisting of 7.10 isodiametric cells which are smaller than those of the receptacle; in the upper part of appendage cells exhibiting triangular additional cells usually occurring on the inner side of the appendage and often giving rise to secondary thin-walled branchlets.

Total length 150-180 $\mu \mathrm{m}$, perithecia 90-115 × 35-43 $\mu \mathrm{m}$, receptacle 50-65 $\mu \mathrm{m}$, appendage up to $75 \mu \mathrm{m}$.

On Ochthebius minimus Fabr. (Col., Hydrophilidae): Kampinos National Park (Warszawa voiv.): Truskaw, bank of a small pond in the western part of the village, 10.10.1980, leg. T. Majewski (TM. 2428-2429, 2430 - holotype). Fig. 2.

Only few representatives (12 mature specimens) of this species were found on the lower surface of host abdomen. Doubtless this species is scarce, because it was detected only recently, although I have inspected very many beetles of genus 


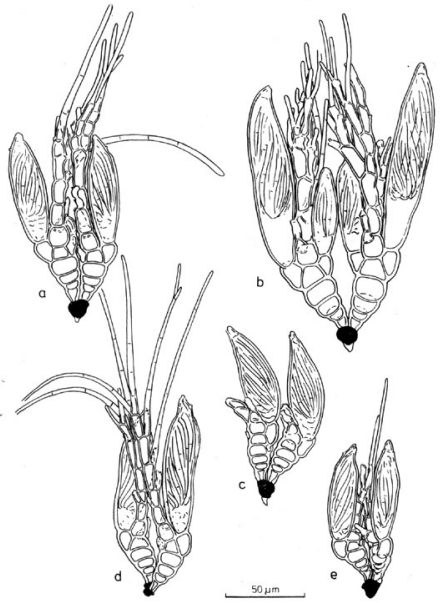

Fig. 1. Euphoriomyces huggerii sp.n. on Proteinus brachypterus

a-c - Wetlina $(a-$ holotype $)$ on Acrulia inflata $d, e-$ Berezki

Ochthebius from various Polish stands. This species differs from the so far described species of genus Hydrophilomyces (and from $\mathrm{H}$. digitatus Picard on Ochthebius marinus) in its stout habit, characteristically bent top of perithecium and hemispherical protuberance under this top, as well as in the sharp-pointed thick-walled buffer cells. 


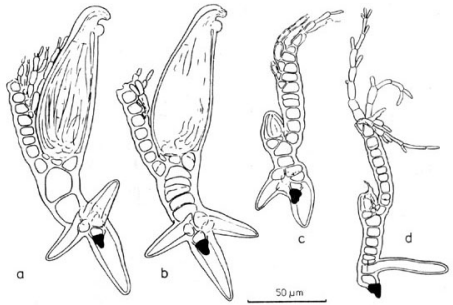

Fig 2. Hydrophilomyces pusiltus sp.n on Ochrhehius minimus, Truskaw:

af - boloispe b.ä-inotypes

Laboulbenia corylophi Scheloske

On Corylophus cassidoides Marsh. (Col., Orthoperidae): vicinity of Przemyst (Przemyśl voiv.), leg. Tadeusz T rell a (TM. 2104).

I found 8 specimens on host elytra in the collection of the Institute of Systematic and Experimental Zoology. Polish Academy of Sciences, Cracow. All are the same age, mature, dark coloured, however with more or less damaged appendages. With respect to structure and dimensions, they correspond to a great extent to the drawing and description of S cheloske (1969).

\section{Rickia georgii sp. $\mathrm{n}$.}

Thallus hyalinus, late falcatis. Series media ex octo bis decem cellulis, series posterior plerumque ex septem cellulis, tertia vel quaria singulas cellulas appendiculatas habet. Appendix primarius elongatus, discretus, excellula basali elongata el cuabus cellulis parvis distalibus compositus. Series anterior e six cellulis, una vel duas singulas cellulas appendiculatas habent. Antheridium sub basin perithecii, partim immersum, sine septo denigrato. Appendices elongatae, simplices, raro ramosac. Longitudo toia 70-83 $\mu \mathrm{m}$, perithecia 33-38 $\times 16-18 \mu \mathrm{m}$, appendices ad $53 \mathrm{~m}$.

Hyaline, triseriate. The body broadly and asymetrically falcate. Basal cell relatively large, obtriangularly elogatac. The median series of eigth to ten cells, four of which beside the perithecium; the lowermost cell longer than broad, the remai- 


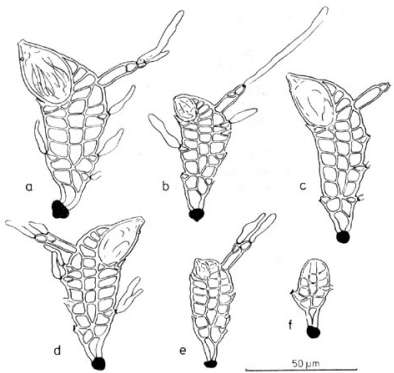

Fig. 3. Rickia 2xeorgü sp.n. on Hypoaspis cuncifer

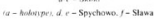

ning cells isodiametric or flattened. The posterior series of seven (rarely six) irregularly isodiametric or flattened cells, three or four of which with a single appendiculate cell and elongate appendage. This series ending in the elongate discrete basal cell of the primary appendage, bearing distally two small cells with septa and appendages. The anterior series of six cells, one or two of them separating single appendiculate cells, and the upper cell of the series separating an antheridium. Appendages simple, rarely furcate. Antheridium near the base of the perithecium, without black septum, its base immersed. Perithecium late ovate, externally free, with a short neck.

Total length $70-83 \mu \mathrm{m}$, perithecia $33-38 \times 16-18 \mu \mathrm{m}$, appendages up to 53 $\mu \mathrm{m}$.

On Hypoaspis cuneifer Mich. (Acarina, Dermanyssidae): Skoki (Poznan voiv.). in nest of Lasius flavus Fabr., 23.10.1980, leg Andrzej Sokotowsk i (TM.2347, 2348, 2349 - holotype); Spychowo (Olsztyn voiv.), in nest of Lasius flavis, 25.10.1980, leg. Mariusz L u to m s k i (TM. 2350, 2351); Sława (Poznań voiv.), in nest of Lasius flavus, 23.10.1980, leg. A. So k o to w s k i (TM. 2352). Fig. 3. 
On distal parts of the anterior legs of hosts eleven specimens, in most cases not fully mature, were found. They most resemble Rickia discreta and $R$. hypoaspitis, described by $\mathrm{T}$ h axter $(1912,1924)$, which also parasitize representatives of Acarina. The newly described species differs from them in greater size and in a more elongated and protruding primary appendage, with a dissimilar structure on top (in Rickia discreta and $R$. hypoaspitis this appendage comprises only two cells of nearly equal length). In both above species, the receptacle cells (particularly the median series) are fewer and rather elongated than flattened, as compared with $R$. georgii.

Idedicate this species to Prof. Jerzy (=Georgius) W iśn i e w s k i, Agricultural University in Poznani, to whose unusual kindness I owe already the second new taxon of genus Rickia, parasitizing mites occuring in ant nests.
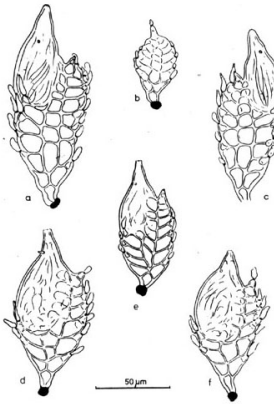

Fig. 4. Rickia proteini sp.n. on Proteinus brachypterus 


\section{Rickia proteini sp. $\mathrm{n}$.}

Thallus hyalinus, late fusiformis. Series media ex septem vel octo cellulis formata, superiores gradatim minores sunt. Series posterior ex sex bis octo cellulis, omnes singulam cellulam appendiculatam cum brevi appendice vel antheridio habent. Series anterior ex quinque cellulis, quarum omnes praeter unam infimam unam vel duas cellulas appendiculatas cum appendice vel antheridio separant. Perithecium obovatum, ad apicem angustatur, margo eius externa libera.

Altiudo tota 100-140 × 40-50 $\mathrm{\mu m}$, perithecia 50-70 × 25-28 $\mathrm{\mu m}$.

Hyaline, triseriate. The body broadly fusiform in outline, on the rather short, obtriangular basal cell. The median series of seven or eight cells, ending beside the middle part of perithecium. The lowest cell great and elongate; other cells gradually smaller towards the highest one. The margin cells irregular, the lowest elongated, the upper somewhat flattened. The posterior series of six to eight cells, each bearing one appendiculate cell with black septum and short appendage or pointed antheridium. The primary appendage short, its lower cell immersed, the upper small, triangular. The anterior series of five cells; with exception of the lowest cell, they bear one or two appendiculate cells with appendages or antheridia. Perithecium erect or slightly inward tipped, obovate, pointed toward the apex, externally free.

Total dimensions 100-140 $\times$ 40-50 $\mu \mathrm{m}$, perithecia 50-70 $\times 25-28 \mu \mathrm{m}$.

On Proteinus brachypterus F. (Col., Staphylinidae): Bieszczady Mts., Tarnica Mt. (Krosno voiv.), in Fagetum, on Russula sp., $1200 \mathrm{~m}$ above sea level, 21.8.1964, leg. Andrzej S z u j e c k i (TM. 1682-holotype); Tatra National Park (Nowy Sącz. voiv.), Spadowiec Valley, in Fagetum, on decaying agarics, $950 \mathrm{~m}, 21.8 .1979$ (TM.2313, 2314); as previously, Strażyska Valley, forest with Picea abies, on Clavaria sp., 1100 m, 22.8 .1979 (TM. 2315-2317), leg. T. M a jew s k i. Fig. 4, a-c.

The structure of Rickia proteini resembles that of the other recently described species parasitizing Staphylinidae: Rickia zanettii (W. Ross i et C es a r i 1978) and Rickia huggertii and $R$. hyperborea (B a lazuc 1980). Rickia proteini is particularly close to the two latter ones. It differs from Rickia hyperborea (on Micralymma spp.) in a shorter median series, this causing the perithecium to be internally half-free; in Rickia huggertii (on Homalium spp.) the median and posterior series are more expanded.

A parasite of Proteinus macropterus Gyll. (Fig. 4, d-f), also occuring in Poland, resembles the above-described fungus from Proteinus brachypterus. However, it somewhat differs from typical Rickia proteini. The length of perithecium is usually much greater than half the thallus length (in $R$. proteini it is smaller). There are fewer receptacle cells (median series: $6-7$, posterior series: $6-7$, anterior series: 3 , rarely 4 cells); sterile appendages are also less numerous, particularly on the anterior series. Dimensions of fungus from Proteinus macropterus: 80-108 $\times 33-50$ 
$\mu \mathrm{m}$, perithecia $50-68 \times 25-35 \mu \mathrm{m}$. It is probably a variety of Rickia proteini. I found it at the following stands: Bialowieza (Bialystok voiv.), 20.5.1981 (TM. 2438); Różan (Ostrołęka voiv.), 15.7.198। (TM. 2511); Jarostaw (Przemyśl voiv.), 16.8.1982 (TM. 2669-2672).

\section{Acknowledgements}

I am thankful to Dr. S, M a z u r, Institute of Forest Protection, Agricultural Academy. Warsaw, for the determination of beetles of families Staphylinidae, Anthicidae and Cryptophagidae, to Doc.Dr. K. G a l e w s k i, Institute of Zoology, Polish Academy of Sciences, for the determination of representatives of Hydrophilidae, and to Mrs. M. Korz y bs k a for help in translation of the Latin diagnoses. I am particularly indebted to Prof. Dr. J. W i s n i e w s $k$ i from Poznań, for the infected specimens of Hypoaspis.

\section{REFERENCES}

B a I a z u c J., 1980 L aboulbéniales nouvelles (Ascomycẻtes), parasites de Coléoptères el de Dipières. Bull. Mus nation. Hist nat. Paris, sér. 4, 2 B: 209-219.

B à n heg y i J., 1944. A Balaton környékének Laboulbenia-félëi. Bot. Közlem. 41: 49.61.

Ma i re R., 1920. Troisième contribution à l'étude des Laboullx́niales de l’Afrique du Nord. Bull. Soc.

Hist. Nat. Afrique Nord 11: 123-138, 143-170.

Majewski T, 1973. Rare and new Laboulbeniales from Poland. IV. Acta Mycol. 9: 229-238.

Rossi W., Cesari Rossi M. G., 1978. Contributo alla conoscenza delle Laboulbeniali (Ascomycetes) parassite di Stafilinidi italiani (Insecta, Coleoptera), Giom, Bot. Ital. 112: 63-74.

Scheloske H. W., 1969. Beiträge zur Biologie, Ökologie und Systematik der Laboulberiales (Ascomycetes) unter besonderer Berücksichtigung des Parasit-Wirt-Verhälınisses. Parasitolog. Schr. Reihe 19:1-176.

Th a xt e r R., 1908, 1924, 1931. Contribution towards a monograph of the Laboulbeniaceae. Part II: III: V. Mem. Amer. Acad. Arts Sci. 13(6): 217-469, pl. 28-71; 14(5): 309-426, pl. 1-22; I6(l): 1.435, pl. $1-60$.

Th a x ter R., 1912. Preliminary descriptions of new species of Rickia and Trenomyces. Proc. Amer. Acad. Arts Sci. 48: 363-386.

\section{Rzadkie i nowe Laboulbeniales z Polski. VIII}

\section{Streszczenie}

W pracy podano stanowiska 10 nowych dla Polski gatunków Laboulbeniales, w tym nowych dla nauki: Euphoriomyces huggertii na Proteinus brachypterus i Acrulia inflata. Hydrophilomyces pusillus na Ochthebius minimus, Rickia georgii na Hypoaspis cumeifer i Rickia proteini na Proteinus spp. 